\title{
Effects of leaf length and development stage on the triple oxygen isotope signature of grass leaf water and phytoliths: insights for a proxy of continental atmospheric humidity
}

\author{
Anne Alexandre ${ }^{1}$, Elizabeth Webb ${ }^{2}$, Amaelle Landais $^{3}$, Clément Piel $^{4}$, Sébastien Devidal ${ }^{4}$, Corinne Sonzogni $^{1}$, \\ Martine Couapel $^{1}$, Jean-Charles Mazur ${ }^{1}$, Monique Pierre ${ }^{2}$, Frédéric Prié ${ }^{2}$, Christine Vallet-Coulomb ${ }^{1}$, \\ Clément Outrequin ${ }^{1}$, and Jacques $\operatorname{Roy}^{4}$ \\ ${ }^{1}$ Aix Marseille Univ, CNRS, IRD, INRA, Coll France, CEREGE, Aix-en-Provence, France \\ ${ }^{2}$ Department of Earth Sciences, The University of Western Ontario, London, Ontario, Canada \\ ${ }^{3}$ Laboratoire des Sciences du Climat et de l'Environnement (LSCE/IPSL/CEA/CNRS/UVSQ), Gif-sur-Yvette, France \\ ${ }^{4}$ Ecotron Européen de Montpellier, Univ Montpellier, UPS 3248 CNRS, Campus Baillarguet, Montferrier-sur-Lez, France
}

Correspondence: Anne Alexandre (alexandre@cerege.fr)

Received: 1 March 2019 - Discussion started: 27 March 2019

Revised: 4 October 2019 - Accepted: 5 November 2019 - Published: 5 December 2019

\begin{abstract}
Continental relative humidity (RH) is a key climate parameter, but there is a lack of quantitative RH proxies suitable for climate model-data comparisons. Recently, a combination of climate chamber and natural transect calibrations have laid the groundwork for examining the robustness of the triple oxygen isotope composition $\left(\delta^{18} \mathrm{O}\right.$ and ${ }^{17} \mathrm{O}$ excess) of phytoliths, that can preserve in sediments, as a new proxy for past changes in RH. However, it was recommended that besides $\mathrm{RH}$, additional factors that may impact $\delta^{18} \mathrm{O}$ and ${ }^{17} \mathrm{O}$-excess of plant water and phytoliths be examined. Here, the effects of grass leaf length, leaf development stage and day-night alternations are addressed from growth chamber experiments. The triple oxygen isotope compositions of leaf water and phytoliths of the grass species $F$. arundinacea are analysed. Evolution of the leaf water $\delta^{\prime 18} \mathrm{O}$ and ${ }^{17} \mathrm{O}$-excess along the leaf length can be modelled using a string-of-lakes approach to which an unevaporatedevaporated mixing equation must be added. We show that for phytoliths to record this evolution, a kinetic fractionation between leaf water and silica, increasing from the base to the apex, must be assumed. Despite the isotope heterogeneity of leaf water along the leaf length, the bulk leaf phytolith $\delta^{\prime 18} \mathrm{O}$ and ${ }^{17} \mathrm{O}$-excess values can be estimated from the Craig and Gordon model and a mean leaf water-phytolith fractionation exponent ( $\lambda_{\text {Phyto-LW }}$ ) of 0.521 . In addition to not being leaf length dependent, $\delta^{18} \mathrm{O}$ and ${ }^{17} \mathrm{O}$-excess of grass phytoliths are expected to be impacted only very slightly by the stem vs.
\end{abstract}

leaf biomass ratio. Our experiment additionally shows that because a lot of silica polymerises in grasses when the leaf reaches senescence (58\% of leaf phytoliths in mass), RH prevailing during the start of senescence should be considered in addition to $\mathrm{RH}$ prevailing during leaf growth when interpreting the ${ }^{17} \mathrm{O}$-excess of grass bulk phytoliths. Although under the study conditions ${ }^{17} \mathrm{O}$-excessphyto do not vary significantly from constant day to day-night conditions, additional monitoring at low RH conditions should be done before drawing any generalisable conclusions. Overall, this study strengthens the reliability of the ${ }^{17} \mathrm{O}$-excess of phytoliths to be used as a proxy of RH. If future studies show that the mean value of 0.521 used for the grass leaf water-phytolith fractionation exponent $\lambda$ Phyto-LW is not climate dependent, then grassland leaf water ${ }^{17} \mathrm{O}$-excess obtained from grassland phytolith ${ }^{17} \mathrm{O}$ excess would inform on isotope signals of several soil-plantatmosphere processes.

\section{Introduction}

Recently, a combination of growth chamber and natural transect calibrations laid the groundwork for examining the robustness of the triple oxygen isotope composition (expressed by ${ }^{17} \mathrm{O}$-excess $=\delta^{\prime 17} \mathrm{O}-0.528 \cdot \delta^{\prime 17} \mathrm{O}$ ) of phytoliths as a new proxy for past changes in continental atmospheric relative 
humidity (RH) (Alexandre et al., 2018). Continental RH is a key climate parameter. When combined with atmospheric temperature, it can be used to estimate the concentration of atmospheric water vapour, one of the main components of the global water cycle. However, global climate models have difficulties to properly capture continental RH (Sherwood et al., 2010; Risi et al., 2012; Fischer and Knutti, 2013), and there is a lack of RH proxies suitable for model-data comparisons.

Phytoliths are micrometric particles of hydrous amorphous silica $\left(\mathrm{SiO}_{2}\left(\mathrm{H}_{2} \mathrm{O}\right)_{\mathrm{n}}\right)$ that form in and between living plant cells. Silica polymerises from the sap that contains dissolved silicon (among other nutrients) absorbed by the plant roots from the soil. Phytoliths can take the shape of the cells they form in, which gives them morphological taxonomic properties. Hence, phytolith morphological assemblages extracted from buried soils, loess and sediments are commonly used for palaeoenvironmental reconstructions (Miyabuchi and Sugiyama, 2015; Nogué et al., 2017; Woodburn et al., 2017). In grasses, silica, that represents several percent of the dry weight (d.w.), polymerises mainly in the leaf epidermis from where the plant water evaporates during transpiration (Alexandre et al., 2011; Kumar et al., 2016), and to a much lesser extent in the stem (Webb and Longstaffe, 2000). This polymerisation is assumed to occur in isotope equilibrium with the plant water (Alexandre et al., 2018; Shahack-Gross et al., 1996; Webb and Longstaffe, 2000).

Variations in the ${ }^{17} \mathrm{O}$-excess of plant water can exceed most of the variations identified so far in seawater, surface water, rainfall and ice (Landais et al., 2006; Li et al., 2017; Sharp et al., 2018; Alexandre et al., 2018). They are mainly driven by evaporative fractionation of the transpired water in the leaves. The extent of this fractionation partly depends on atmospheric RH (Cernusak et al., 2016; Craig and Gordon, 1965), which changes daily, seasonally and at longer timescales of climate change. In rainfall the ${ }^{17} \mathrm{O}$-excess varies slightly as it is weakly affected by temperature (Barkan and Luz, 2005; Uemura et al., 2010) or phase changes during air mass transport, in contrast to the deuterium-excess $\left(\mathrm{d}\right.$-excess $\left.=\delta^{2} \mathrm{H}-8.0 \times \delta^{18} \mathrm{O}\right)$. In surface waters, the ${ }^{17} \mathrm{O}$-excess is a powerful tool for tracing very evaporative conditions (Gázquez et al., 2018; Surma et al., 2015, 2018). The ${ }^{17} \mathrm{O}$-excess of waters imprints the ${ }^{17} \mathrm{O}$ excess of minerals formed in isotope equilibrium with these waters (Gázquez et al., 2017; Herwartz et al., 2017; Passey et al., 2014; Sharp et al., 2016, 2018).

In Alexandre et al. (2018), the ${ }^{17} \mathrm{O}$-excess of phytoliths from a grass species (Festuca arundinacea) grown in a climate chamber was examined. A linear relationship with RH was demonstrated. This relationship was close to the one obtained for soil phytoliths collected in West Africa along a vegetation and RH transect. This relationship allowed for the prediction of RH with a standard error of 5.6\%. However, it was recommended that, besides RH, additional factors that may impact the ${ }^{17} \mathrm{O}$-excess of bulk phytolith samples should be examined before using this relationship as a proxy of past RH.

In particular, in nature, the biomass of grass stem, sheath and blade, as well as the leaf length is highly species dependent. Previous studies showed that for grasses the water $\delta^{18} \mathrm{O}$ increases from stem to leaf and from the bottom to the tip of the leaf blade (e.g. Gan et al., 2002; Helliker and Ehleringer, 2000; Farquhar and Gan, 2003; Webb and Longstaffe, 2003; Cernusak et al., 2016). The ${ }^{17} \mathrm{O}$-excess of grass water also shows variation along the leaf (Landais et al., 2006). This raises the question whether diversity in grass physiognomy impacts the relationship between the ${ }^{17} \mathrm{O}$-excess of phytoliths and RH.

Silica precipitate throughout the grass's life, mainly, but not exclusively, in the epidermis. The process can be either metabolically controlled or passive, i.e. depending mainly on silica saturation during cell dehydration when the leaf water evaporates (Kumar et al., 2017, 2019 and references therein). The contribution of evaporated water to the bulk leaf water may vary with transpiration (Cernusak et al., 2016), which changes from day to night (Caird et al., 2007) and decreases drastically when the start of senescence occurs (Norton et al., 2014). This raises the question whether RH changes from day to night and from leaf growth to leaf senescence should be considered when interpreting the ${ }^{17} \mathrm{O}$-excess of phytoliths as a $\mathrm{RH}$ proxy.

In order to address these issues, a growth chamber experiment was set up to explore the influence of light-dark and day-night alternations on the ${ }^{17} \mathrm{O}$-excess and $\delta^{\prime 18} \mathrm{O}$ of leaf water and phytoliths of $F$. arundinacea. Another experiment allowed us to examine the evolution of water and phytolith ${ }^{17} \mathrm{O}$-excess and $\delta^{\prime 18} \mathrm{O}$ values along the leaf, and from young to adult and senescent leaves of $F$. arundinacea. Leaf water and phytoliths were extracted and analysed for $\delta^{18} \mathrm{O}$ and $\delta^{17} \mathrm{O}$. Silica concentrations were measured. Phytolith morphological assemblages that give information on the type of tissue and cells that are silicified were identified. The observed ${ }^{17} \mathrm{O}$-excess and $\delta^{18} \mathrm{O}$ values of leaf water and phytolith-forming water are compared with Craig and Gordon (1965)-derived evaporation model estimates. This comparison allows us to assess the processes driving the ${ }^{17} \mathrm{O}-$ excess and $\delta^{18} \mathrm{O}$ values of grass leaf water and phytoliths. Implications for the calibration of the RH proxy are discussed.

\section{Notations in the triple oxygen isotope system}

In the triple oxygen isotope system $\left(\delta^{18} \mathrm{O}, \delta^{17} \mathrm{O}\right)$ the fractionation factors $\left({ }^{17} \alpha\right.$ and $\left.{ }^{18} \alpha\right)$ are related by the exponent $\theta$, where ${ }^{17} \alpha={ }^{18} \alpha^{\theta}$ or $\theta=\ln ^{17} \alpha / \ln ^{18} \alpha$. For the silica-water couple, and according to the Sharp et al. (2016) empirical Eq. (10), $\theta_{\text {silica-water }}$ equals 0.524 for the $5-35^{\circ} \mathrm{C}$ temperature range. For the water liquid-water vapour couple at equilibrium, $\theta_{\text {equil }}$ equals 0.529 for the $11-41{ }^{\circ} \mathrm{C}$ range (Barkan 
and Luz, 2005). When evaporation occurs, a fractionation due to the vapour diffusion in air is added to the equilibrium fractionation, as conceptualised by the Craig and Gordon model (Craig and Gordon, 1965; Gat, 1996). $\theta_{\text {diff associated }}$ with this diffusion fractionation equals 0.518 (Barkan and Luz, 2007). When RH decreases, amplitude of the fractionation governed by $\theta_{\text {diff }}$ increases. While $\theta$ applies to a particular well-constrained physical process, the term $\lambda$ is used when several fractionation processes occur at the same time. The overall fractionation in the triple oxygen isotope system can be formulated as following: $\lambda=\Delta^{\prime 17} \mathrm{O}_{\mathrm{A}-\mathrm{B}} / \Delta^{\prime 18} \mathrm{O}_{\mathrm{A}-\mathrm{B}}$, with $\Delta^{\prime 17} \mathrm{O}_{\mathrm{A}-\mathrm{B}}=\delta^{\prime 17} \mathrm{O}_{\mathrm{A}}-\delta^{\prime 17} \mathrm{O}_{\mathrm{B}}, \Delta^{\prime 18} \mathrm{O}_{\mathrm{A}-\mathrm{B}}=\delta^{\prime 18} \mathrm{O}_{\mathrm{A}}-$ $\delta^{18} \mathrm{O}_{\mathrm{B}}, \delta^{\prime 17} \mathrm{O}=\ln \left(\delta^{17} \mathrm{O}+1\right)$ and $\delta^{\prime 18} \mathrm{O}=\ln \left(\delta^{18} \mathrm{O}+1\right) . \delta$ and $\delta^{\prime}$ notations are expressed in \%o vs. VSMOW. In the $\delta^{\prime 18} \mathrm{O}$ vs. $\delta^{\prime 17} \mathrm{O}$ space, $\lambda$ represents the slope of the line linking $\Delta^{\prime 17} \mathrm{O}_{\mathrm{A}-\mathrm{B}}$ to $\Delta^{\prime 18} \mathrm{O}_{\mathrm{A}-\mathrm{B}}$. In hydrological studies, the triple oxygen isotope composition of water is expressed by the ${ }^{17} \mathrm{O}$-excess $\left({ }^{17} \mathrm{O}\right.$-excess $\left.=\delta^{\prime 17} \mathrm{O}-0.528 \times \delta^{\prime 18} \mathrm{O}\right)$. In the $\delta^{\prime 17} \mathrm{O}$ vs. $\delta^{\prime 18} \mathrm{O}$ space, the ${ }^{17} \mathrm{O}$-excess depicts the $\delta^{\prime 17} \mathrm{O}$ departure from a reference line with a slope $\lambda$ of 0.528 . This is the slope of the Global Meteoric Water Line (expressed as $\delta^{\prime 17} \mathrm{O}=-0.528 \times \delta^{\prime 18} \mathrm{O}+0.33$ per meg; Luz and Barkan, 2010). The average ${ }^{17} \mathrm{O}$-excess of meteoric waters range from 35 to 41 per meg (Luz and Barkan, 2010; Sharp et al., 2018). As the reference slope is close to the liquid-vapour equilibrium exponent $\theta_{\text {equil }}(0.529)$, the ${ }^{17} \mathrm{O}$-excess is very convenient to highlight kinetic processes that result from evaporation.

\section{Material}

In three growth chambers, the grass species $F$. arundinacea was sown and grown in commercial potting soil in a $35 \mathrm{~L}$ container $(53 \mathrm{~cm} \times 35 \mathrm{~cm} \times 22 \mathrm{~cm}, L \times W \times D)$. A total of $10 \mathrm{~d}$ after germination, agar-agar was spread on the soil surface around the seedlings to prevent any evaporation from the soil as described in Alexandre et al. (2018). Ambient RH was kept constant in the growth chamber by combining a flow of dry air and an ultrasonic humidifier that produces vapour without any isotope fractionation. The vapour and the soil irrigation water (IW) came from the same source, and their triple oxygen isotope composition was similar $(-5.59 \%$ and 26 per meg for $\delta^{18} \mathrm{O}$ and ${ }^{17} \mathrm{O}$-excess, respectively).

\subsection{Experiment 1}

This experiment was designed to examine the grass leaf water and phytolith isotope signatures in different parts of the leaf and at different stages of the leaf development. Briefly, the stages considered were (i) young leaf, where only the end of the blade is visible as it emerges from the sheath of the preceding leaf; (ii) adult leaf where the blade is fully developed, the ligule is visible and the sheath is well formed; and (iii) yellow and desiccated senescent leaf.
F. arundinacea was grown for $39 \mathrm{~d}$, in a climate chamber where light, air temperature and RH were set constant at $290 \mu \mathrm{mol} \mathrm{m}^{-2} \mathrm{~s}^{-1}, 20^{\circ} \mathrm{C}$ and $73 \%$, respectively. On day 28 , irrigation was stopped to force senescence of the leaves. A total of $197 \mathrm{~g}$ of biomass was collected $11 \mathrm{~d}$ later. From this biomass, young leaf (visible end of the blade), adult leaf and senescent leaf (blade only) were separated. Adult leaves, of $24 \mathrm{~cm}$ length in average, were sectioned into three parts: sheath, proximal part of the blade $(10 \mathrm{~cm}$ long) and apical part of the blade. Five samples resulted (Table 1). For all samples, except the senescent leaves, 3-5 g biomass were put in gastight glass vials and kept frozen for bulk leaf water extraction. Senescent leaves were too dry for water extraction. The rest of the biomass (between 10 and $70 \mathrm{~g}$ depending on the sample, Table 1) was dried for phytolith extraction.

\subsection{Experiment 2a}

Light triggers the opening of plant stomata with, as an inevitable consequence, an increase in water loss through these stomata. At night, however, stomata often do not close totally. Night transpiration is often $5 \%$ to $15 \%$ of day transpiration (Caird et al., 2007). In $F$. arundinacea, stomatal conductance at night can be as high as $30 \%$ of conductance during the day (Pitcairn et al., 1986). Together with difference in air RH between day and night, this could affect isotope enrichment of leaf water (Barbour et al., 2005). This experiment was thus designed to assess whether light-dark alternation may impact the isotope signature of $F$. arundinacea leaf water.

In a growth chamber, $F$. arundinacea was grown for $22 \mathrm{~d}$ with constant light. Then, a $12 \mathrm{~h}$ light $-12 \mathrm{~h}$ dark alternation was introduced. Temperature and $\mathrm{RH}$ were kept constant at $25^{\circ} \mathrm{C}$ and $60 \%$, respectively. Half of the biomass was harvested at the end of day 22 (constant light). Then the alternation period was set up, and the second half of the biomass was harvested at the end of day 26. In order to consider potential spatial heterogeneity, leaf blades (both young and adult leaves) were collected from four different places in the culture for each harvest. The eight resulting samples (Table S1 in the Supplement) were put in gastight glass vials and kept frozen for bulk leaf water extraction.

\subsection{Experiment 2b}

In natural conditions, day-night alternations imply changes in temperature and RH in addition to changes in light intensity. This experiment was designed to assess whether over a period of several day-night alternations, changes in RH during the night impacted the mean isotope signature of grass leaf phytoliths.

For this experiment, the leaf water was not analysed as it only gives a snapshot of its isotope composition. F. arundinacea was grown in two growth chambers. In the first chamber, light, temperature and $\mathrm{RH}$ were kept constant 

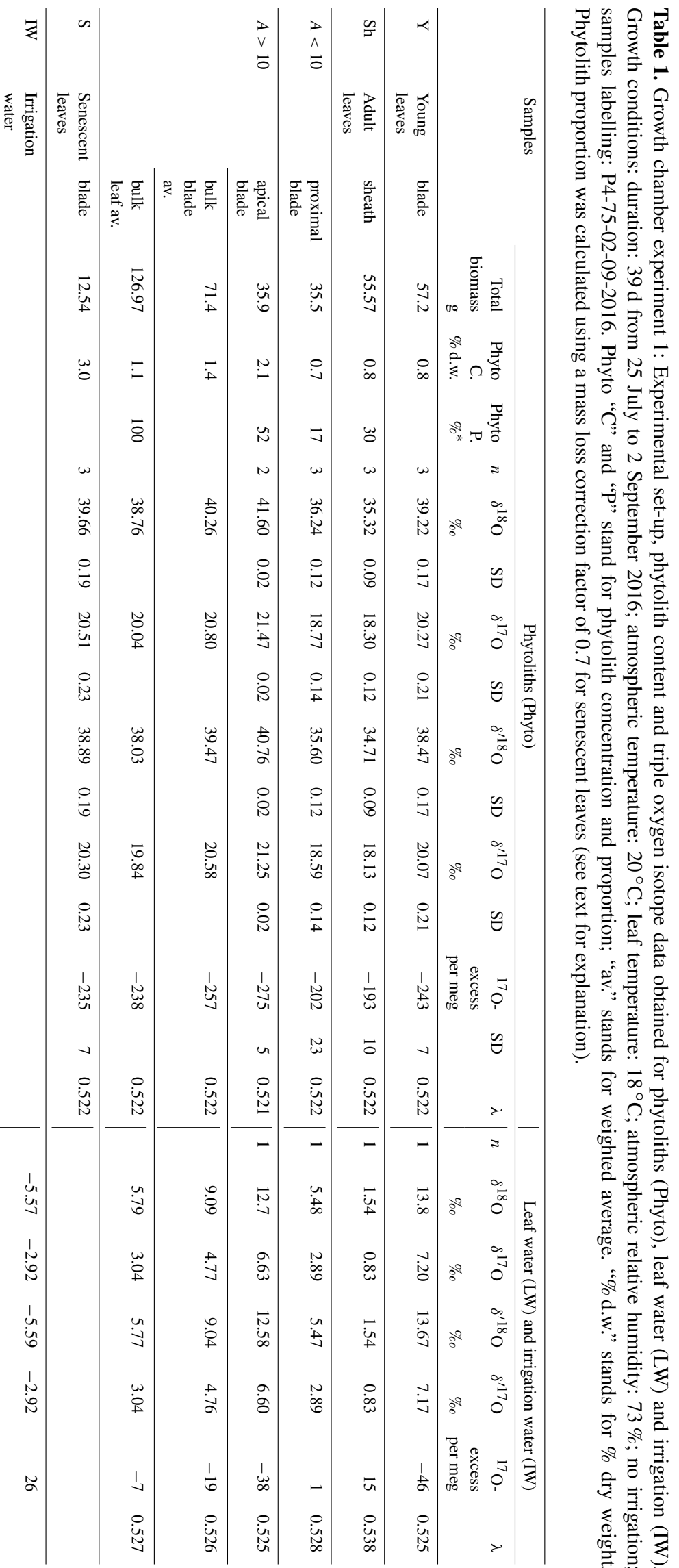
( $290 \mathrm{mmol} \mathrm{m}^{-2} \mathrm{~s}^{-1}, 25^{\circ} \mathrm{C}$ and $60 \%$, respectively). In the second chamber, $12 \mathrm{~h}$ day- $12 \mathrm{~h}$ night alternations were set. During the day (light $290 \mu \mathrm{mol} \mathrm{m}{ }^{-2} \mathrm{~s}^{-1}$ ), temperature and $\mathrm{RH}$ were set to $25^{\circ} \mathrm{C}$ and $60 \%$, respectively, whereas during the night (no light) they were set to $20^{\circ} \mathrm{C}$ and $80 \%$, respectively. The leaf blades (both young and adult leaves) were harvested after a first growth of $16 \mathrm{~d}$ and a second growth of $18 \mathrm{~d}$ (Table S1) and dried for phytolith extraction.

\section{Methods}

\subsection{Phytolith chemical extraction, counting and analysis}

Phytoliths were extracted using a high-purity protocol with $\mathrm{HCl}, \mathrm{H}_{2} \mathrm{SO}_{4}, \mathrm{H}_{2} \mathrm{O}_{2}, \mathrm{HNO}_{3}, \mathrm{KClO}_{3}$ and $\mathrm{KOH}$ at $70^{\circ} \mathrm{C}$ following Corbineau et al. (2013) and Alexandre et al. (2018). Phytoliths were weighed and their mass reported to the initial leaf dry weight (d.w.). To account for leaf mass loss during senescence, a mass loss correction factor of 0.7 , previously estimated for graminoids (Vergutz et al., 2012), was applied to the phytolith concentration in senescent leaves (Table 1).

Most grass phytoliths have a morphology characteristic of their cell of origin. Phytolith morphological assemblages were thus determined to follow the spatial evolution over time of the leaf silicification. Phytoliths assemblages from experiment 1 were mounted on microscope slides in Canada Balsam and counted using light microscopy at a $600 \times$ magnification. More than 200 phytoliths with a dimension greater than $5 \mu \mathrm{m}$ and with a characteristic morphology were counted. Phytolith types were named using the International Code for Phytolith Nomenclature 1.0 (Madella et al., 2005) and categorised as follows: "trapeziform short cell" and "trapeziform sinuate short cell" coming from the short cell silicification, "elongate cylindric" and "elongate echinate" coming from the intercoastal long cell silicification, "acicular" produced by hair silicification and "parallelepipedal" produced by bulliform cells silicification (Table 1, Fig. 1). These characteristic phytoliths are commonly used for palaeoenvironmental reconstructions when recovered from buried soils or sediments (e.g. Woodburn et al., 2017). In addition, thin silica particles with uncharacteristic shape and with a refractive index too low to be accurately described using light microscopy were also counted. Abundance of the phytolith categories are expressed in percentage of the sum of counted particles. Three repeated counts usually give an error lower than $\pm 5 \%$ (SD). The phytolith assemblages were further observed with a scanning electron microscope (FEG-SEM, HITACHI SV6600, accelerating voltage of $3 \mathrm{KV}, 15^{\circ}$ tilt, working distance of $14 \mathrm{~mm}$ and probe current of a few picoampere to avoid charging issues), after carbon coating.

Phytoliths triple oxygen isotope analysis was performed as described in details in Alexandre et al. (2018). The in-

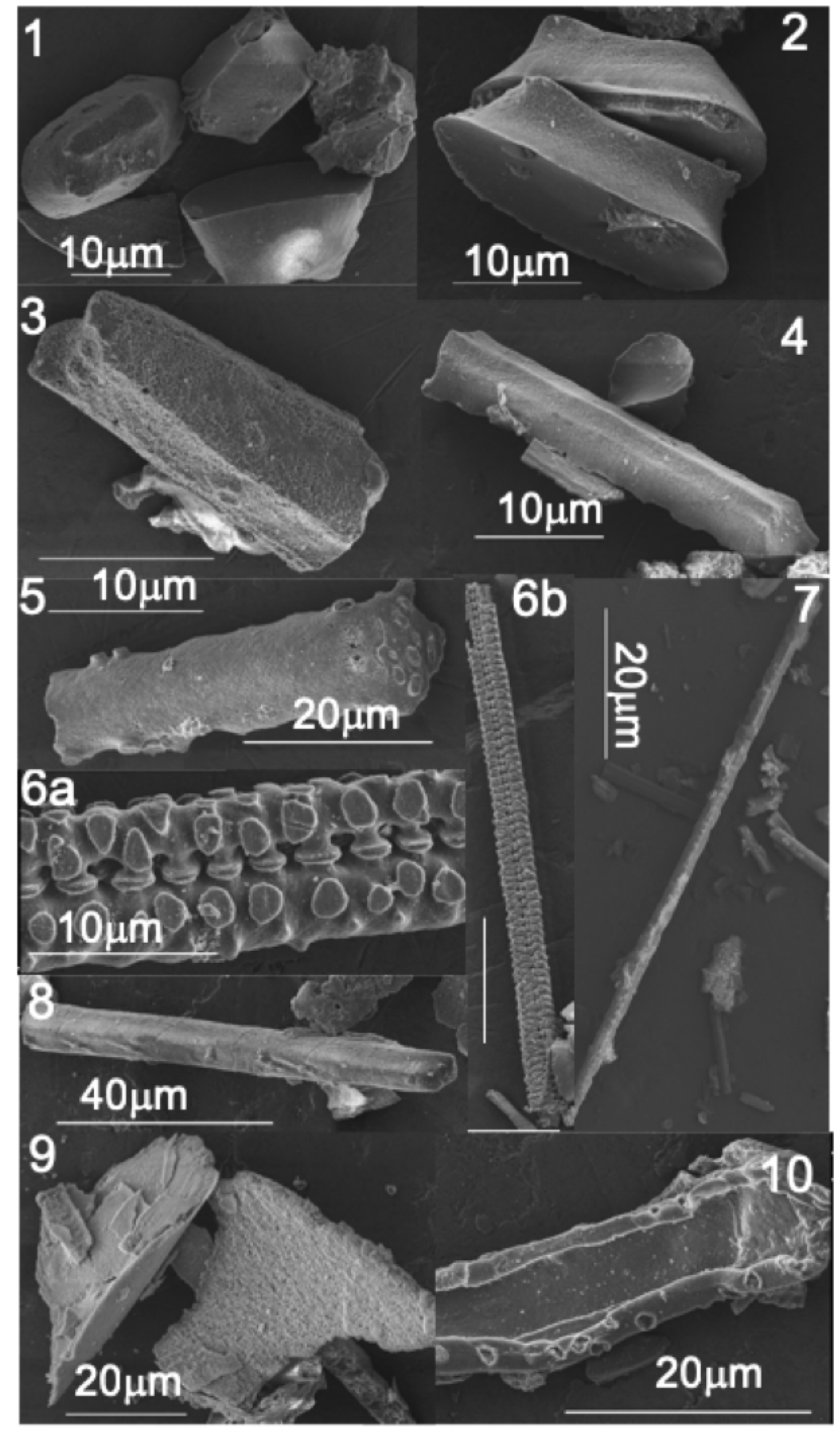

Figure 1. Growth chamber experiment 1: SEM pictures of phytoliths from young, adult and senescent leaf blade: silicified trapeziform short cell (1,2 and 3), silicified trapeziform sinuate short cell (4), undefined silicified short cell or broken elongate cylindric long cell (5), silicified elongate cylindric long cell (6a, 6b, 7 and 8) and silicified cell wall also reported as silica sheets (9 and 10).

frared (IR) laser-heating fluorination technique (Alexandre et al., 2006; Crespin et al., 2008; Suavet et al., 2010) was used to extract the oxygen gas $\left(\mathrm{O}_{2}\right)$ after dehydration and dehydroxylation under a flow of $\mathrm{N}_{2}$ (Chapligin et al., 2010). Then, the $\mathrm{O}_{2}$ was passed through $\mathrm{a}-114^{\circ} \mathrm{C}$ slush to refreeze gases interfering with the mass 33 (e.g. NF). These interfering gases may be produced during the fluorination of residual $\mathrm{N}$ in the line. The purified $\mathrm{O}_{2}$ was sent to a dual-inlet mass spectrometer (ThermoQuest Finnigan Delta Plus). The composition of the reference gas was determined through the analyses of NBS28 for which isotope composition has been set to $\delta^{18} \mathrm{O}=9.60 \%$ ov. VSMOW, $\delta^{17} \mathrm{O}=4.99 \%$ vs. 
VSMOW and ${ }^{17} \mathrm{O}$-excess $=65$ per meg. Each analysis consisted of two runs of eight dual-inlet measurements with an integration time of $26 \mathrm{~s}$. The sample isotope compositions were corrected on a daily basis using a quartz laboratory standard (Boulangé) with $\delta^{18} \mathrm{O}=16.284 \%$ vs. VSMOW, $\delta^{17} \mathrm{O}=8.463 \%$ vs. VSMOW. During the measurement period, Boulangé reproducibility (SD) was $\pm 0.13 \%$ o, $\pm 0.07 \%$ 。 and \pm 11 per meg for $\delta^{18} \mathrm{O}, \delta^{17} \mathrm{O}$ and ${ }^{17} \mathrm{O}$-excess, respectively $(n=9)$. For a given sample, two to three phytoliths aliquots were analysed. Measured reproducibility ranged from 5 to 23 per meg for ${ }^{17} \mathrm{O}$-excess.

\subsection{Leaf water extraction and analysis}

Leaf water was extracted over $6 \mathrm{~h}$ using a distillation line. Then a fluorination line was used to convert water to oxygen using $\mathrm{CoF}_{3}$. Oxygen was analysed by dual-inlet IRMS (ThermoQuest Finnigan MAT 253) against a working $\mathrm{O}_{2}$ standard calibrated against VSMOW. The detailed procedure was previously described in Landais et al. (2006) and Alexandre et al. (2018). The reproducibility (two replicates) was $0.015 \%$ for $\delta^{17} \mathrm{O}, 0.010 \%$ for $\delta^{18} \mathrm{O}$ and 5 per meg for ${ }^{17} \mathrm{O}$-excess.

\subsection{Irrigation and vaporisation water analysis}

The irrigation and vaporisation waters were analysed with an isotope laser analyser (Picarro L2140-i) operated in ${ }^{17} \mathrm{O}$ excess mode using an autosampler and a high-precision vaporiser as described in detail in Alexandre et al. (2018). The reproducibility (three replicates) was $0.02 \%, 0.01 \%$ and 10 per meg for $\delta^{17} \mathrm{O}, \delta^{18} \mathrm{O}$ and ${ }^{17} \mathrm{O}$-excess, respectively.

\section{Results}

\subsection{Phytolith concentration, assemblage and origin in grass leaf (experiment 1)}

From young to adult and senescent blade, the phytolith content increases sharply from $0.8 \%$ d.w. to $1.1 \%$ d.w. and $3.0 \%$ d.w. (Table 1). This makes $58 \%$ of blade phytoliths precipitating at the start of senescence. In adult leaves, the phytolith concentration of $0.8 \%$ d.w. and $0.7 \%$ d.w. in the sheaths and proximal blade increases to $2.1 \%$ d.w. in the apical blade. This makes apical blade phytoliths representing $52 \%$ of adult leaf phytoliths.

Short cell phytoliths are found in all samples, while long cell phytoliths are absent from the adult sheath (Table S2). The ratio of long cell vs. short and long cell phytoliths increases with phytolith concentration from young (29\% of counted phytoliths) to adult (49\% of counted phytoliths) and senescent (67\% of counted phytoliths) leaf blades (Fig. 2). In adult leaves, it increases from sheath ( $1 \%$ of counted phytoliths) to proximal (19\% of counted phytoliths) and apical (59\% of counted phytoliths) blades. Parallelepipedal bulliform and acicular hair phytoliths can be observed but in

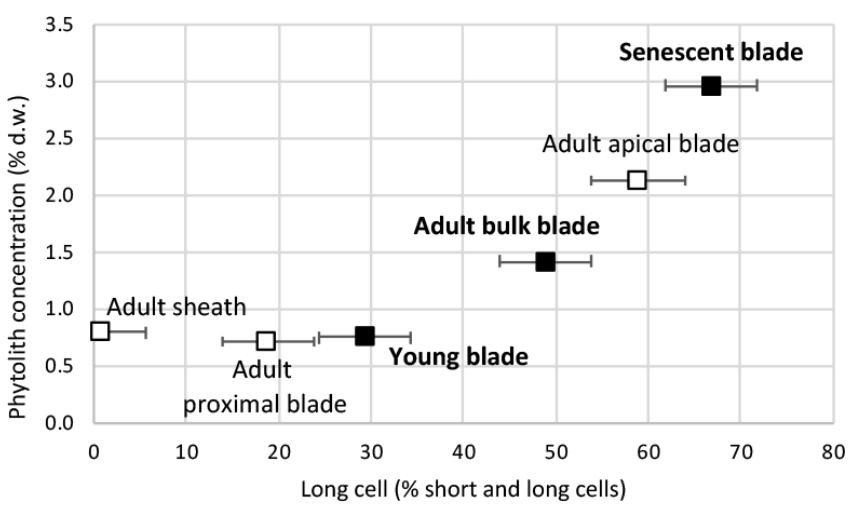

Figure 2. Growth chamber experiment 1: Phytolith concentration vs. long cell phytolith proportion. Error bars represent the $5 \%$ error on counting (refer to text for details).

small amounts $(<2 \%$ of counted phytoliths) in young and senescent leaf blade samples. All phytolith assemblages contain thin silica particles with low refractive index, difficult to count with accuracy in light microscopy. SEM observation shows they are composed of multi-cellular silica sheets (mostly silicified cell walls and a few silicified stomata complexes) (Fig. 1, Table S2). Their abundance ranges from $24 \%$ to $18 \%$ of counted phytoliths in young and adult blades and increases up to $52 \%$ of counted phytoliths in senescent leaf blades. Because these silica sheet particles are very thin, their weight contribution to the isotope signature of bulk phytolith assemblages is expected to be significantly lower than their number.

\subsection{Heterogeneity in the triple oxygen isotope composition of leaf water}

Irrigation and leaf water (IW and LW, respectively) $\delta^{18} \mathrm{O}$, $\delta^{\prime 17} \mathrm{O}$, and ${ }^{17} \mathrm{O}$-excess values obtained from experiment 1 are presented in Table 1 and Fig. 3. As expected, the lowest $\delta^{\prime 18} \mathrm{O}_{\mathrm{LW}}$ and $\delta^{\prime 17} \mathrm{O}_{\mathrm{LW}}$ values occur in the adult leaf sheath. The sheath water is still ${ }^{18} \mathrm{O}$-enriched by $7.1 \%$ relative to the irrigation water, whereas the difference in ${ }^{17} \mathrm{O}$-excess is not significant (11 per meg). In adult leaf waters, an evaporative fractionation trend $\left({ }^{17} \mathrm{O}\right.$-excess $s_{\mathrm{LW}-\mathrm{IW}}$ decreases and $\delta^{\prime 18} \mathrm{O}_{\mathrm{LW}}$ increases) occurs from the sheath to the proximal and apical blade. Water from the young leaf blade plots close to the adult apical blade.

\subsection{Heterogeneity in the triple oxygen isotope composition of leaf silica}

When plotted in the ${ }^{17} \mathrm{O}$-excess vs. $\delta^{18} \mathrm{O}$ space (Fig. 3), the triple oxygen isotope composition of phytoliths in adult leaf also show a clear evaporative fractionation trend from the sheath to the proximal and apical blade. $\lambda_{\text {Phyto-LW decreases }}$ from 0.522 in the sheath and proximal blade to 0.521 in the apical blade (Table S2). 

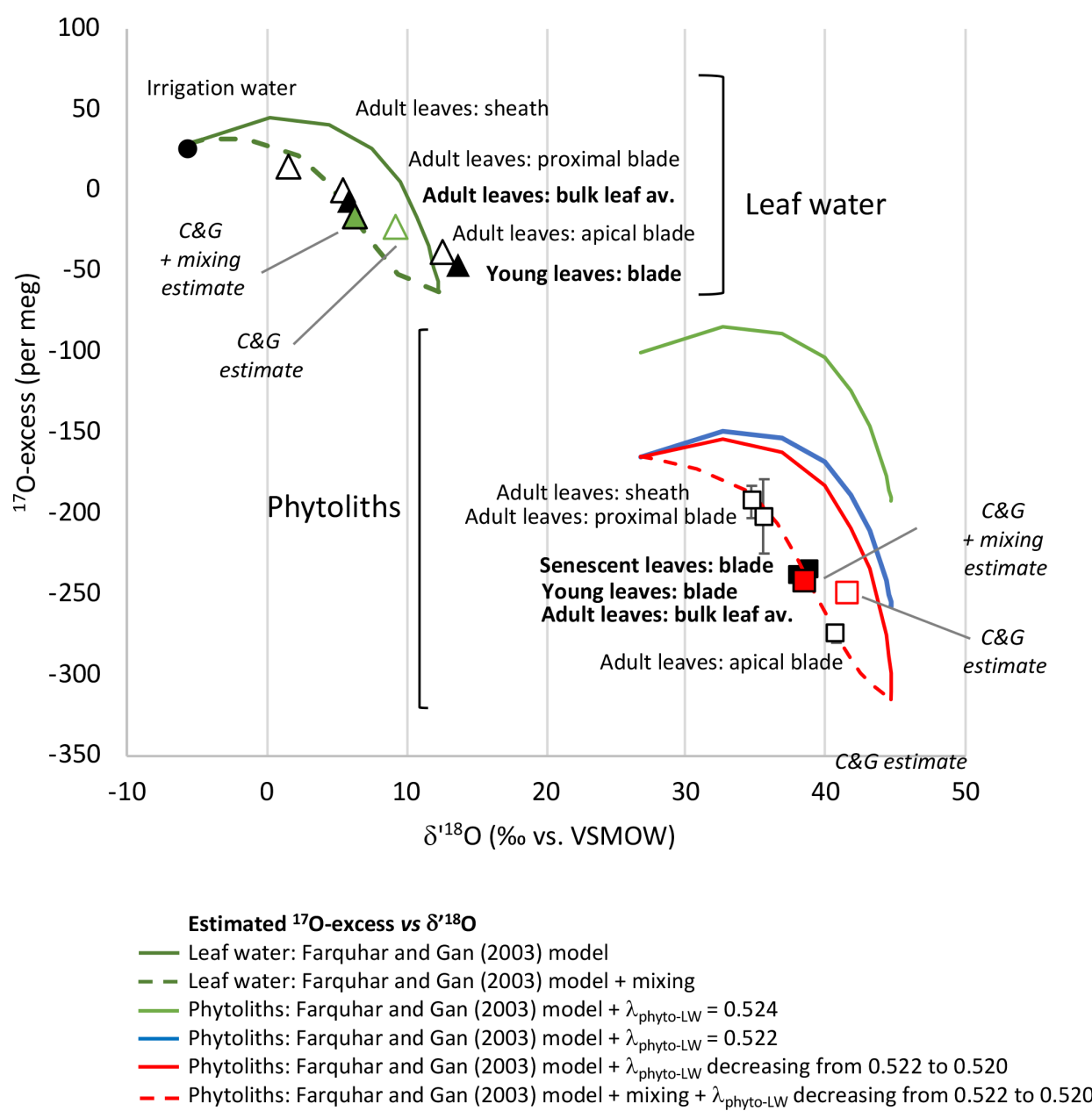

Figure 3. Growth chamber experiment 1: leaf water and phytolith triple oxygen isotope data and estimates. Observed ${ }^{17} \mathrm{O}$-excess vs. $\delta^{18} \mathrm{O}$ for leaf water (triangles) and phytoliths (squares) in young, adult and senescent leaves (black symbols) and along adult leaf (sheath, proximal blade, apical blade) (white symbols) (Table 1). Error bars are displayed when larger than the symbols. Estimated ${ }^{17} \mathrm{O}$-excess vs. $\delta^{\prime 18} \mathrm{O}$ for bulk leaf water (Table S3) and along the leaf length (Table S4) according to the Craig and Gordon (C\&G) model (Cernusak et al., 2016; Farquhar et al., 2007) and the C\&G model complemented with a mixing equation.

Given the measurement precision, young, adult and senescent blades have close $\delta^{\prime 18} \mathrm{O}_{\text {Phyto }}(38.47,39.47,38.89 \%$, respectively) and ${ }^{17} \mathrm{O}$-excessphyto $(-243,-257$ and -235 per meg, respectively) values (Table S2). The ${ }^{17} \mathrm{O}$-excessphyto value of the bulk leaf $(-238$ per meg) is very close to the estimate calculated from the ${ }^{17} \mathrm{O}$-excess Phyto vs. $\mathrm{RH}$ relationship obtained from growth chamber experiment in Alexandre et al. (2018) ( -222 per meg).

\subsection{Effect of light-dark and day-night alternation on the triple oxygen isotope composition of leaf water and leaf silica}

Plant water isotope data from experiment 2a where lightdark alternations were set without changing $\mathrm{RH}$, are presented in Table S1. Variations within a given set of samples (e.g. F4-02-03-17 Day or F4-02-03-17 Night in Table S1) are important, alerting that interpretation in term of kinetic vs. equilibrium fractionation of small variations of $\delta^{18} \mathrm{O}_{\mathrm{LW}}$ $\left(<1 \%\right.$ o or ${ }^{17} \mathrm{O}$-excess $\mathrm{LW}_{\mathrm{LW}}(<14$ per meg) should be avoided. When considering the margins of error, the averaged values of $\delta^{\prime 18} \mathrm{O}_{\mathrm{LW}}$ and ${ }^{17} \mathrm{O}$-excess $\mathrm{SW}_{\mathrm{LW}}$ obtained after the dark period are similar to the ones obtained after the light period. It was not possible to measure the night and day transpiration flows or the stomatal conductance during the experiment. In experiment $2 b$, where temperature and $\mathrm{RH}$ changed with light-dark alternations, transpiration and leaf blade phytolith concentrations did not change by more than $0.1 \mathrm{Ld}^{-1}$ and $0.2 \%$ d.w., respectively, when light was set constant or alternates with dark (Table S1). Differences in $\delta^{\prime 18} \mathrm{O}_{\text {Phyto }}$ and ${ }^{17} \mathrm{O}$-excess Phyto are lower than $1.4 \%$ and 30 per meg, respectively, but are not always in the same direction. In summary, under the experimental set up conditions (high RH), light- 
dark alternation has no obvious impact on the oxygen triple isotope composition of leaf water and phytoliths.

\section{Discussion}

\subsection{Silicification dynamics}

The phytolith content and assemblages obtained from experiment 1 can be discussed in light of previous studies investigating silica deposition in grasses. At the cell level, silicification, which is a rapid process taking a few hours (Kumar and Elbaum, 2017), initiates either in the extra-membranous space or in the cell wall and proceeds centripetally until the cell lumen is filled up (Bauer et al., 2011). During cell lumen silicification, some cells are still viable and transfer their content to each other before their full silicification $(\mathrm{Ku}-$ mar and Elbaum, 2017). Long and short cell phytoliths polymerise that way. Cell wall silicification, not followed by complete cell lumen filling, has been also frequently observed both in the epidermis (Kumar et al., 2017) and in the bundle sheath parenchyma cells surrounding the veins (Motomura, 2004). Cell wall silicification produces the multi-cellular silica sheets observed in the phytolith samples from experiment 1 .

Over the course of leaf development, short cells are the first to silicify. This silicification is metabolically controlled (Kumar et al., 2017, 2019 and references therein). Then, when the leaves become mature, long cell silicification takes over (Motomura, 2004; Kumar et al., 2016). In this case, silicification is supposed to be passive, i.e. its extent depends on silica saturation during cell dehydration at the evaporation sites. Passive silicification applies also to bulliform and hair cell silicification (Kumar et al., 2017, 2019 and references therein). Increase of long vs. long and short cell phytoliths from young to adult and senescent leaf blade, observed in experiment 1 (Fig. 2), confirms this pattern of silicification when the leaf develops. Cell wall silicification added to short and long cell silicification occurs mainly when the leaf reaches senescence.

\subsection{Impact of leaf length on the triple oxygen isotope compositions of grass leaf water}

$\delta^{18} \mathrm{O}_{\mathrm{LW}}$ of the bulk leaf water can be estimated from the Craig and Gordon model applied to plant leaf water by Farquhar et al. (2007) (Table S3, adapted from spreadsheet provided in Cernusak et al., 2016). For that purpose, the grass transpiration is supposed to be at steady state as climatic conditions were set constant during the $39 \mathrm{~d}$ of growth. We also assumed that the vapour has the same isotope composition as the irrigation water since (i) the vaporised water comes from the same source as the irrigation water and is not fractionated by the vaporiser, (ii) there is no soil evaporation and (iii) transpiration should produce a vapour with a composition similar to the one of the soil water pumped by the roots (e.g. Welp et al., 2008). We measured the temperature of an adult leaf of $F$. arundinacea grown under conditions similar to those of experiment 1 . The leaf was systematically $2{ }^{\circ} \mathrm{C}$ cooler than the surrounding air and no significant temperature difference was detected between the sheath, proximal and apical blade. Thus, the model was run for a leaf temperature of $18.4^{\circ} \mathrm{C}$. For estimating the $\delta^{17} \mathrm{O}_{\mathrm{LW}}$, we used the equilibrium and kinetic fractionation $\left({ }^{17} \alpha_{\mathrm{eq}}\right.$ and ${ }^{17} \alpha_{K}$, respectively, Table S3) calculated according to ${ }^{17} \alpha_{\mathrm{eq}}={ }^{18} \alpha_{\mathrm{eq}}^{0.529}$ and ${ }^{17} \alpha_{k}={ }^{18} \alpha_{k}^{0.518}$.

The bulk leaf water $\delta^{\prime 18} \mathrm{O}_{\mathrm{LW}}$ estimate is $3.35 \%$ o higher than the observed value. However, the ${ }^{17} \mathrm{O}$-excess $\mathrm{LW}$ estimate is only 16 per meg lower than the observed one (Table S3, Fig. 3). $\delta^{18} \mathrm{O}_{\mathrm{LW}}$ (and thus $\delta^{18} \mathrm{O}_{\mathrm{LW}}$ ) overestimation is common, and different corrections have been proposed to take into account advection of less evaporated stem water in the bulk leaf water (synthesis in Cernusak et al., 2016). Assuming a mixture between evaporated water and irrigation water, with the proportion of evaporated water $(E)$ being 0.8 , brings the estimated isotope composition of the bulk leaf water close to the observed one (differences in $\delta^{\prime 18} \mathrm{O}_{\mathrm{LW}}$ and ${ }^{17} \mathrm{O}$-excess $\mathrm{LW}_{\mathrm{LW}}$ of $0.43 \%$ and 10 per meg, respectively) (Table S3 and Fig. 3). Our experimental setup, where the vapour isotope composition is similar to the irrigation isotope composition and RH is relatively high, makes the ${ }^{17} \mathrm{O}$-excess $\mathrm{LW}_{\mathrm{LW}}$ weakly sensitive to unevaporated water advection. However, this should not be the case under natural conditions, especially at low RH.

For modelling the strong increase in $\delta^{\prime 18} \mathrm{O}_{\mathrm{LW}}$, concomitant with a ${ }^{17} \mathrm{O}$-excess $\mathrm{LW}_{\mathrm{LW}}$ decrease from the irrigation water to the sheath, proximal and apical blade of the leaf, the string-of-lakes approach (Gat and Bowser, 1991; Helliker and Ehleringer, 2000; Farquhar and Gan, 2003) can be used. This approach, which implies progressively ${ }^{18} \mathrm{O}$-enriched water segments along the leaf, is particularly adapted to the longitudinal veinal structure of grasses. Using the Farquhar and Gan (2003) Eqs. (2), (3) and (5), we calculated $\delta^{18} \mathrm{O}_{\mathrm{LW}}$ and $\delta^{17} \mathrm{O}_{\mathrm{LW}}$ from 0 to $24 \mathrm{~cm}$ length (Table S4). In the triple oxygen isotope space, the modelled curve (green continuous curve in Fig. 3) is characteristic of an evaporation trend (Surma et al., 2018). The ranges of estimated and observed $\delta^{\prime 18} \mathrm{O}_{\mathrm{LW}}$ and ${ }^{17} \mathrm{O}$-excess $\mathrm{LW}$ values are close. However, the observed data plot systematically on the left of the modelled curve. A mixture between evaporated water and irrigation water must be added for the new modelled curve (green dashed curve in Fig. 3) to fit the data. This presumes that part of the irrigation water entering the grass circulates in the parallel veinal structure of the blade without participating to the pool of water successively evaporated. The contribution of evaporated water ( $E$ in Table S4) increases from 0 at the leaf base to 1 at the apex. According to this new modelled curve, the sheath, where stomata are few but still present (e.g. Chaffey, 1985), already contains about $60 \%$ of evaporated water. This is in agreement with previous observations showing ${ }^{18} \mathrm{O}$ enrichment in the sheath of different grass species 
(Webb and Longstaffe, 2003). The fact that the isotope signature of the young blade plots close to the signature of the apical adult leaf blade suggests that the young leaf proximal part was not entirely sampled. More importantly, the stringof-lakes model implies that the $\delta^{\prime 18} \mathrm{O}_{\mathrm{LW}}$ and ${ }^{17} \mathrm{O}$-excess $\mathrm{LW}$ values do not evolve as a function of absolute leaf length but as a function of distance relative to the maximum leaf length (Table S3). This makes both the maximum ${ }^{18} \mathrm{O}$ and ${ }^{17} \mathrm{O}$ enrichments in the grass leaf apical part and the isotope composition of grass bulk leaf water independent of grass leaf length.

\subsection{Impact of leaf length on the triple oxygen isotope compositions of grass leaf phytoliths}

Polymerisation of silica is supposed to occur in isotope equilibrium with the formation water, and, therefore, its isotope composition should only be governed by temperature and the isotope composition of the leaf water (Alexandre et al., 2018; Dodd and Sharp, 2010; Sharp et al., 2016). From the $\delta^{\prime 18} \mathrm{O}_{\mathrm{LW}}$ and $\delta^{\prime 17} \mathrm{O}_{\mathrm{LW}}$ values estimated using the string-of-lakes approach, we calculated $\delta^{18} \mathrm{O}_{\text {Phyto }}$ and ${ }^{17} \mathrm{O}$ excess Phyto (Table S4). We used two thermo-dependent relationships, empirically established from diatom samples, to calculate ${ }^{18} \alpha_{\text {Phyto-LW }}, \delta^{18} \mathrm{O}_{\text {Phyto }}$ (Dodd and Sharp, 2010) and

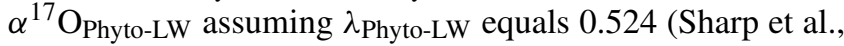
2016, Eq. 10).

In the ${ }^{17} \mathrm{O}$-excess vs. $\delta^{18} \mathrm{O}$ space, the modelled phytolith curve (green curve on Fig. 3) is above the data observed for phytoliths from the sheath, proximal and apical blade. Changing values for ${ }^{18} \alpha_{\text {Phyto-LW }}$ or for leaf temperature, stomatal or boundary layer conductance, air vapour or leaf vapour pressure in the model, do not reconciliate observed and estimated isotope compositions. Assuming a $\lambda_{\text {Phyto-LW }}$ value of 0.522 moves the modelled curve (blue curve on Fig. 3) lower but still above the observed data. $\lambda$ Phyto-LW must decrease from 0.522 to 0.520 , from the base to the apex of the leaf, for the modelled curve (red continuous curve on Fig. 3) to encompass the observed ${ }^{17} \mathrm{O}$-excessphyto values. When the mixing hypothesis previously described for modelling the leaf water composition with length is added, the new modelled curve (red dashed curve on Fig. 3) correctly fits the data.

For the adult bulk leaf $\delta^{18} \mathrm{O}_{\text {Phyto }}$ and ${ }^{17} \mathrm{O}$-excessphyto estimates to be nearest to the observed values, a mean $\lambda$ Phyto-LW value must be set at 0.521 . In this case, the estimated

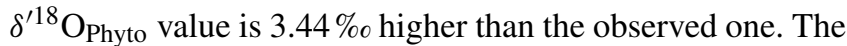
estimated ${ }^{17} \mathrm{O}$-excessphyto value is similar to the observed one (10 per meg difference, Table S3, Fig. 3). Adding a mixing process with $E$ equals to 0.8 (as is the case for the bulk adult leaf water estimate, refer to Sect. 6.1) brings the $\delta^{\prime 18} \mathrm{O}_{\text {Phyto }}$ estimate very close to the observed one (differences in $\delta^{18} \mathrm{O}_{\text {Phyto and }}{ }^{17} \mathrm{O}$-excess Phyto of $0.51 \%$ and 6 per meg, respectively) (Table S3 and Fig. 3).
The comparison between modelled and observed isotope compositions brings insights on the factors driving $\delta^{\prime 18} \mathrm{O}_{\text {Phyto }}$ and ${ }^{17} \mathrm{O}$-excess Phyto in grass leaves. The $\lambda$ Phyto-LW value being lower than the $\theta_{\text {silica-water value of } 0.524 \text { calculated after }}$ Sharp et al. (2016) implies that either the $\theta_{\text {silica-water value }}$ previously established is overestimated or a kinetic fractionation occurs during phytolith formation. Our modelling exercise suggests that the amplitude of such a kinetic fractionation would increase from the base to the apex of the leaf ( $\lambda$ Phyto-LW decreasing regularly from 0.522 to 0.520 ). The proportion of short cell phytoliths for which silica polymerisation is genetically controlled, decreases from the base to the apex (Table S2). This would go against a kinetic fractionation being enzymatically controlled. However, further knowledge on the mechanisms of silica polymerisation is needed to further discuss this point.

Positions of the phytolith data on the modelled phytolith curve are not exactly the same as positions of the leaf water data of the modelled leaf water curve, especially for the apical part. This discrepancy suggests that $E$ in the apical leaf water is higher than $E$ in the phytolith-forming water. This can be explained assuming the following: phytolith-forming water integrates the whole grass elongation period (Kumar et al., 2016, 2019; Kumar and Elbaum, 2017) while the sampled leaf water only represents a snapshot. In grass leaf, the epidermal cells close to the apex were produced at the base of the leaf and pushed upward during the growth. Hence apical epidermal cells are older than the cells close to the base, and phytoliths in these cells gather early and late phytoliths that are formed at long and short distances relative to the maximal length, with low and high $E$ values, respectively.

For the grass bulk leaf, despite this discrepancy along leaf

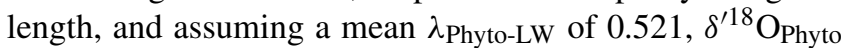
and ${ }^{17} \mathrm{O}$-excessphyto record $\delta^{\prime 18} \mathrm{O}_{\mathrm{LW}}$ and ${ }^{17} \mathrm{O}$-excess $\mathrm{LW}$. In other terms, whatever the grass leaf length, $\delta^{18} \mathrm{O}_{\text {Phyto and }}$ ${ }^{17} \mathrm{O}$-excessphyto should be determinable from the Craig and Gordon model complemented by an unevaporatedevaporated water mixing equation. The main controls on $\delta^{\prime 18} \mathrm{O}_{\text {Phyto and }}{ }^{17} \mathrm{O}$-excessphyto are thus the soil water and vapour isotope compositions, the difference of temperature between leaf water and atmosphere, RH and $E$.

\subsection{Potential impact of stem phytoliths on the triple oxygen isotope compositions of grass phytoliths}

In addition to grass leaf length, the stem vs. leaf biomass ratio can be very heterogeneous from one grass development stage to another and from one grass genus to another. Previous studies showed that phytoliths from grass stems represent less than $10 \%$ d.w. of the overall above-ground grass silica content (e.g. Webb and Longstaffe, 2002) even in grasses with high stem biomass such as bamboos (e.g. Ding et al., 2008). Stem phytoliths are only weakly enriched in ${ }^{18} \mathrm{O}$ compared to leaf phytoliths (Webb and Longstaffe, 2006). Thus, the contribution of stem phytoliths to a soil phytolith assem- 
blage should slightly decrease $\delta^{18} \mathrm{O}_{\text {Phyto }}$ and increase ${ }^{17} \mathrm{O}$ excess Phyto average values. Assuming a ${ }^{17} \mathrm{O}$-excessphyto difference between stem and bulk leaf of 200 per meg, this would lead to a ${ }^{17} \mathrm{O}$-excessphyto value for stem $(10 \%$ d.w.) and leaf ( $90 \%$ d.w.) phytolith assemblage higher by 20 per meg relative to an only leaf phytolith assemblage, which is lower than the lowest reproducibility obtained when measuring three aliquots of phytoliths ( 23 per meg). We conclude that grass physiognomy should impact only very slightly the triple oxygen isotope composition of bulk grass phytoliths.

\subsection{Impact of senescence on the triple oxygen isotope composition of grass phytoliths}

Our data show that $58 \%$ of leaf phytoliths form at the end of the growth when the leaf reaches senescence. Leaf senescence is age related or a stress-induced developmental ageing during which transpiration decreases to minimal level but is still efficient (Norton et al., 2014) as epidermal conductance progressively prevails over stomatal conductance (Smith et al., 2006). If the cells already contain dissolved silica, epidermal evaporation, not balanced by water input due to decreasing transpiration at the start of leaf senescence, may lead to silica saturation and polymerisation. Thus, the bulk phytolith assemblage of a senescent leaf will gather phytoliths formed during both the leaf growth and start of senescence. In our experimental conditions, where RH stays constant during both periods, the triple isotope composition of phytoliths stays constant. However, in nature, if RH decreases (e.g. due to seasonal decrease of precipitation in Mediterranean and tropical areas or to colder temperatures in temperate areas) when generalised grass leaf senescence occur, then both periods should be considered when assessing the ${ }^{17} \mathrm{O}$-excess Phyto vs. RH relationship from bulk phytolith assemblages from plant, soil or sediment.

\subsection{Impact of day-night alternations on the triple oxygen isotope composition of leaf water and leaf silica}

The results obtained from experiment 2a show very close isotope compositions of leaf water during light and dark periods. The constancy of atmospheric relative humidity and temperature, as well as the shortness of experiment $2 \mathrm{a}$ ( $4 \mathrm{~d}$ with dark-light alternations after more than 2 months of constant daylight) may have played against the closure of the stomata at dark. A previous study on elongating leaves of $F$. arundinacea showed that spatial distribution of water content within the elongation zone can stay almost constant during the dark and light period (Schnyder and Nelson, 1988), supporting that dark/light alternations do not always impact the stomata openness. Anyhow, a sensitivity test shows that whatever the stomatal behaviour, change in stomatal conductance does not impact significantly the Craig and Gordon ${ }^{17} \mathrm{O}$-excess $\mathrm{SW}_{\mathrm{LW}}$ and $\delta^{\prime 18} \mathrm{O}_{\mathrm{LW}}$ estimates. Experiment $2 \mathrm{~b}$ shows that under the study high RH conditions (60\% during the day and $80 \%$ during the night in experiment $2 \mathrm{~b}$ ), transpiration, silicification, $\delta^{\prime 18} \mathrm{O}_{\text {Phyto }}$ and ${ }^{17} \mathrm{O}$-excessphyto do not vary significantly from constant day to day-night conditions.

\section{Conclusions}

The data and estimates presented here contribute to a more precise identification of the parameters to take into consideration when using the ${ }^{17} \mathrm{O}$-excess Phyto as a $\mathrm{RH}$ proxy (Alexandre et al., 2018). Neither grass height nor grass physiognomy should significantly impact the isotope composition of bulk grass leaf water and phytoliths. By contrast, RH prevailing at the start of senescence should be considered in addition to RH prevailing during leaf growth when interpreting ${ }^{17} \mathrm{O}$-excess Phyto. If future studies show that the fractionation between leaf water and phytoliths, expressed by a mean

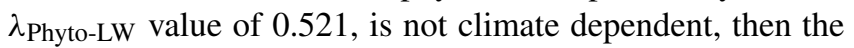
triple oxygen isotope composition of bulk leaf water should be obtainable from the triple oxygen isotope composition of grassland phytolith assemblages. The parameters driving the triple oxygen isotope composition of both grass leaf water and phytoliths are given by the Craig and Gordon model applied to leaves (Farquhar et al., 2007) and the unevaporatedevaporated water mixing equation. Thus the most important parameters are the difference between soil water and vapour isotope compositions, the difference between leaf and atmosphere temperatures, $\mathrm{RH}$ and $E$. Being able to record the triple oxygen isotope composition of grassland leaf water would bring some significant insights into (i) estimating the triple oxygen isotope composition of $\mathrm{CO}_{2}$ equilibrated with leaf water and partitioning gross fluxes of $\mathrm{CO}_{2}$ from vegetation at the regional scale (e.g. Helliker and Ehleringer, 2000) or (ii) estimating at the global scale the triple oxygen isotope composition of $\mathrm{O}_{2}$ produced by the biosphere and quantifying its productivity from air bubbles trapped in ice cores (Blunier et al., 2002).

Data availability. Data may be extracted directly from the current article or requested from the corresponding author.

Supplement. The supplement related to this article is available online at: https://doi.org/10.5194/bg-16-4613-2019-supplement.

Author contributions. AA, AL, CP, SD, CS, MP and JR designed the experiments and carried them out. AA, AL, CP, SD, CS, MC, JCM, MP and FP did the extractions and isotope analyses. AA prepared the paper with contributions from all co-authors.

Competing interests. The authors declare that they have no conflict of interest. 
Acknowledgements. This study benefited from the CNRS human and technical resources allocated to the Ecotrons Research Infrastructure. We thank Daniel Herwartz, Claudia Voigt and an anonymous reviewer for their in-depth reviews that substantially improved the modelling approach and the paper.

Financial support. This research has been supported by INSULEFE and the ANR (grant nos. ANR-17-CE01-0002 and ANR-11INBS-0001).

Review statement. This paper was edited by Christopher Still and reviewed by Daniel Herwartz and one anonymous referee.

\section{References}

Alexandre, A., Basile-Doelsch, I., Sonzogni, C., Sylvestre, F., Parron, C., Meunier, J.-D., and Colin, F.: Oxygen isotope analyses of fine silica grains using laser-extraction technique: Comparison with oxygen isotope data obtained from ion microprobe analyses and application to quartzite and silcrete cement investigation, Geochim. Cosmochim. Ac., 70, 2827-2835, https://doi.org/10.1016/j.gca.2006.03.003, 2006.

Alexandre, A., Bouvet, M., and Abbadie, L.: The role of savannas in the terrestrial Si cycle: A case-study from Lamto, Ivory Coast, Global Planet. Change, 78, 162-169, 2011.

Alexandre, A., Landais, A., Vallet-Coulomb, C., Piel, C., Devidal, S., Pauchet, S., Sonzogni, C., Couapel, M., Pasturel, M., Cornuault, P., Xin, J., Mazur, J.-C., Prié, F., Bentaleb, I., Webb, E., Chalié, F., and Roy, J.: The triple oxygen isotope composition of phytoliths as a proxy of continental atmospheric humidity: insights from climate chamber and climate transect calibrations, Biogeosciences, 15, 3223-3241, https://doi.org/10.5194/bg-153223-2018, 2018.

Barbour, M. M., Cernusak, L., Whitehead, D., Griffin, K., Turnbull, M. H., Tissue, D. T., and Farquhar, G.: Nocturnal stomatal conductance and implications for modelling (delta oxygen 18) of leaf-respired $\mathrm{CO}_{2}$ in temperate tree species, Funct. Plant Biol., 32, 1107-1121, https://doi.org/10.1071/FP05118, 2005.

Barkan, E. and Luz, B.: High precision measurements of ${ }^{17} \mathrm{O} /{ }^{16} \mathrm{O}$ and ${ }^{18} \mathrm{O} /{ }^{16} \mathrm{O}$ ratios in $\mathrm{H}_{2} \mathrm{O}$, Rapid Commun. Mass Sp., 19, 3737-3742, https://doi.org/10.1002/rcm.2250, 2005.

Barkan, E. and Luz, B.: Diffusivity fractionations of $\mathrm{H}_{2}^{16} \mathrm{O} / \mathrm{H}_{2}^{17} \mathrm{O}$ and $\mathrm{H}_{2}^{16} \mathrm{O} / \mathrm{H}_{2}^{18} \mathrm{O}$ in air and their implications for isotope hydrology, Rapid Commun. Mass Sp., 21, 2999-3005, https://doi.org/10.1002/rcm.3180, 2007.

Bauer, P., Elbaum, R., and Weiss, I. M.: Calcium and silicon mineralization in land plants: Transport, structure and function, Plant Sci., 180, 746-756, https://doi.org/10.1016/j.plantsci.2011.01.019, 2011.

Blunier, T., Barnett, B., Bender, M. L., and Hendricks, M. B.: Biological oxygen productivity during the last 60,000 years from triple oxygen isotope measurements, Global Biogeochem. Cy., 16, 3-1, https://doi.org/10.1029/2001GB001460, 2002.

Caird, M. A., Richards, J. H., and Donovan, L. A.: Nighttime Stomatal Conductance and Transpiration in $\mathrm{C}_{3}$ and $\mathrm{C}_{4}$ Plants, Plant
Physiol., 143, 4-10, https://doi.org/10.1104/pp.106.092940, 2007.

Cernusak, L. A., Barbour, M. M., Arndt, S. K., Cheesman, A. W., English, N. B., Feild, T. S., Helliker, B. R., Holloway-Phillips, M. M., Holtum, J. A. M., Kahmen, A., McInerney, F. A., Munksgaard, N. C., Simonin, K. A., Song, X., Stuart-Williams, H., West, J. B., and Farquhar, G. D.: Stable isotopes in leaf water of terrestrial plants, Plant Cell Environ., 39, 1087-1102, https://doi.org/10.1111/pce.12703, 2016.

Chaffey, N. J.: Structure and Function in the Grass Ligule: Presence of Veined and Membranous Ligules on the Same Culm of British Grasses, New Phytol., 101, 613-621, 1985.

Chapligin, B., Meyer, H., Friedrichsen, H., Marent, A., Sohns, E., and Hubberten, H.-W.: A high-performance, safer and semi-automated approach for the $\delta^{18} \mathrm{O}$ analysis of diatom silica and new methods for removing exchangeable oxygen, Rapid Commun. Mass Sp., 24, 2655-2664, https://doi.org/10.1002/rcm.4689, 2010.

Corbineau, R., Reyerson, P. E., Alexandre, A., and Santos, G. M.: Towards producing pure phytolith concentrates from plants that are suitable for carbon isotopic analysis, Rev. Palaeobot. Palyno., 197, 179-185, https://doi.org/10.1016/j.revpalbo.2013.06.001, 2013.

Craig, H. and Gordon, L. I.: Deuterium and Oxygen 18 Variations in the Ocean and the Marine Atmosphere, Consiglio nazionale delle richerche, Laboratorio de geologia nucleare, Pisa, 1965.

Crespin, J., Alexandre, A., Sylvestre, F., Sonzogni, C., Paillès, C., and Garreta, V.: IR laser extraction technique applied to oxygen isotope analysis of small biogenic silica samples, Anal. Chem., 80, 2372-2378, https://doi.org/10.1021/ac071475c, 2008.

Ding, T. P., Tian, S. H., Sun, L., Wu, L. H., Zhou, J. X., and Chen, Z. Y.: Silicon isotope fractionation between rice plants and nutrient solution and its significance to the study of the silicon cycle, Geochim. Cosmochim. Ac., 72, 5600-5615, https://doi.org/10.1016/j.gca.2008.09.006, 2008.

Dodd, J. P. and Sharp, Z. D.: A laser fluorination method for oxygen isotope analysis of biogenic silica and a new oxygen isotope calibration of modern diatoms in freshwater environments, Geochim. Cosmochim. Ac., 74, 1381-1390, https://doi.org/10.1016/j.gca.2009.11.023, 2010.

Farquhar, G. D. and Gan, K. S.: On the progressive enrichment of the oxygen isotopic composition of water along a leaf, Plant Cell Environ., 26, 801-819, 2003.

Farquhar, G. D., Cernusak, L. A., and Barnes, B.: Heavy Water Fractionation during Transpiration, Plant Physiol., 143, 11-18, https://doi.org/10.1104/pp.106.093278, 2007.

Fischer, E. M. and Knutti, R.: Robust projections of combined humidity and temperature extremes, Nat. Clim. Change, 3, 126130, https://doi.org/10.1038/nclimate1682, 2013.

Gan, K. S., Wong, S. C., Yong, J. W. H., and Farquhar, G. D.: ${ }^{18} \mathrm{O}$ spatial patterns of vein xylem water, leaf water, and dry matter in cotton leaves, Plant Physiol., 130, 1008-1021, https://doi.org/10.1104/pp.007419, 2002.

Gat, J. R.: Oxygen and Hydrogen Isotopes in the Hydrologic Cycle, Annu. Rev. Earth Pl. Sc., 24, 225-262, https://doi.org/10.1146/annurev.earth.24.1.225, 1996.

Gat, J. R. and Bowser, C.: The heavy isotope enrichment of water in coupled evaporative systems, in: Stable Isotope Geochemistry: A Tribute to Samuel Epstein, edited by: Taylor Jr., H. P., O’Neil, J. 
R., and Kaplan, I. R., The Geochemical Society Special Publication No. 3, 159-168, 1991.

Gázquez, F., Evans, N. P. and Hodell, D. A.: Precise and accurate isotope fractionation factors $\left(\alpha^{17} \mathrm{O}, \alpha^{18} \mathrm{O}\right.$ and $\left.\alpha \mathrm{D}\right)$ for water and $\mathrm{CaSO}_{4} \cdot 2 \mathrm{H}_{2} \mathrm{O}$ (gypsum), Geochim. Cosmochim. Ac., 198, 259270, https://doi.org/10.1016/j.gca.2016.11.001, 2017.

Gázquez, F., Morellón, M., Bauska, T., Herwartz, D., Surma, J., Moreno, A., Staubwasser, M., Valero-Garcés, B., DelgadoHuertas, A., and Hodell, D. A.: Triple oxygen and hydrogen isotopes of gypsum hydration water for quantitative paleohumidity reconstruction, Earth Planet. Sc. Lett., 481, 177-188, https://doi.org/10.1016/j.epsl.2017.10.020, 2018.

Helliker, B. R. and Ehleringer, J. R.: Establishing a grassland signature in veins: ${ }^{18} \mathrm{O}$ in the leaf water of $\mathrm{C}_{3}$ and $\mathrm{C}_{4}$ grasses, P. Natl. Acad. Sci. USA, 97, 7894-7898, 2000.

Herwartz, D., Surma, J., Voigt, C., Assonov, S., and Staubwasser, M.: Triple oxygen isotope systematics of structurally bonded water in gypsum, Geochim. Cosmochim. Ac., 209, 254-266, https://doi.org/10.1016/j.gca.2017.04.026, 2017.

Kumar, S. and Elbaum, R.: Interplay between silica deposition and viability during the life span of sorghum silica cells, New Phytol., 217, 1137-1145, https://doi.org/10.1111/nph.14867, 2017.

Kumar, S., Milstein, Y., Brami, Y., Elbaum, M., and Elbaum, R.: Mechanism of silica deposition in sorghum silica cells, New Phytol., 213, 791-798, https://doi.org/10.1111/nph.14173, 2016.

Kumar, S., Soukup, M., and Elbaum, R.: Silicification in Grasses: Variation between Different Cell Types, Front. Plant Sci., 8, https://doi.org/10.3389/fpls.2017.00438, 2017.

Kumar, S., Adiram-Filiba, N., Blum, S., Sanchez-Lopez, J. A., Tzfadia, O., Omid, A., Volpin, H., Heifetz, Y., Goobes, G., and Elbaum, R.: Grass silica mineralizer (GSM1) protein precipitates silica in sorghum silica cells, bioRxiv, 518332, https://doi.org/10.1101/518332, 2019.

Landais, A., Barkan, E., Yakir, D., and Luz, B.: The triple isotopic composition of oxygen in leaf water, Geochim. Cosmochim. Ac., 70, 4105-4115, https://doi.org/10.1016/j.gca.2006.06.1545, 2006.

Li, S., Levin, N. E., Soderberg, K., Dennis, K. J., and Caylor, K. K.: Triple oxygen isotope composition of leaf waters in Mpala, central Kenya, Earth Planet. Sc. Lett., 468, 38-50, https://doi.org/10.1016/j.epsl.2017.02.015, 2017.

Luz, B. and Barkan, E.: Variations of ${ }^{17} \mathrm{O} /{ }^{16} \mathrm{O}$ and ${ }^{18} \mathrm{O} /{ }^{16} \mathrm{O}$ in meteoric waters, Geochim. Cosmochim. Ac., 74, 6276-6286, https://doi.org/10.1016/j.gca.2010.08.016, 2010.

Madella, M., Alexandre, A., Ball, T., and ICPN Working Group: International code for phytolith nomenclature 1.0, Ann. Bot.London, 96, 253-260, 2005.

Miyabuchi, Y. and Sugiyama, S.: 90,000-year phytolith records from caldera rim to western foot of Aso Volcano, Japan: Implications for vegetation history since catastrophic eruption, Quaternary Int., 397, 392-403, https://doi.org/10.1016/j.quaint.2015.08.015, 2015.

Motomura, H.: Silica Deposition in Relation to Ageing of Leaf Tissues in Sasa veitchii (CarrieÁre) Rehder (Poaceae: Bambusoideae), Ann. Bot.-London, 93, 235-248, 2004.

Nogué, S., Whicher, K., Baker, A. G., Bhagwat, S. A., and Willis, K. J.: Phytolith analysis reveals the intensity of past land use change in the Western Ghats biodiversity hotspot, Quaternary Int., 437, 82-89, https://doi.org/10.1016/j.quaint.2015.11.113, 2017.
Norton, M. R., Lelièvre, F., and Volaire, F.: Measuring dehydration tolerance in pasture grasses to improve drought survival, Crop Pasture Sci., 65, 828-840, https://doi.org/10.1071/CP14054, 2014.

Passey, B. H., Hu, H., Ji, H., Montanari, S., Li, S., Henkes, G. A., and Levin, N. E.: Triple oxygen isotopes in biogenic and sedimentary carbonates, Geochim. Cosmochim. Ac., 141, 1-25, https://doi.org/10.1016/j.gca.2014.06.006, 2014.

Pitcairn, C. E. R., Jeffree, C. E., and Grace, J.: Influence of polishing and abrasion on the diffusive conductance of leaf surface of Festuca arundinacea Schreb, Plant Cell Environ., 9, 191-196, https://doi.org/10.1111/1365-3040.ep11611633, 1986.

Risi, C., Noone, D., Worden, J., Frankenberg, C., Stiller, G., Kiefer, M., Funke, B., Walker, K., Bernath, P., Schneider, M., Wunch, D., Sherlock, V., Deutscher, N., Griffith, D., Wennberg, P. O., Strong, K., Smale, D., Mahieu, E., Barthlott, S., Hase, F., García, O., Notholt, J., Warneke, T., Toon, G., Sayres, D., Bony, S., Lee, J., Brown, D., Uemura, R., and Sturm, C.: Processevaluation of tropospheric humidity simulated by general circulation models using water vapor isotopologues: 1. Comparison between models and observations, J. Geophys. Res., 117, D05303, https://doi.org/10.1029/2011JD016621, 2012.

Schnyder, H. and Nelson, C. J.: Diurnal Growth of Tall Fescue Leaf Blades: I. Spatial Distribution of Growth, Deposition of Water, and Assimilate Import in the Elongation Zone, Plant Physiol., 86, 1070-1076, https://doi.org/10.1104/pp.86.4.1070, 1988.

Shahack-Gross, R., Shemesh, A., Yakir, D., and Weiner, S.: Oxygen isotopic composition of opaline phytoliths: Potential for terrestrial climatic reconstruction, Geochim. Cosmochim. Ac., 60, 3949-3953, https://doi.org/10.1016/0016-7037(96)00237-2, 1996.

Sharp, Z. D., Gibbons, J. A., Maltsev, O., Atudorei, V., Pack, A., Sengupta, S., Shock, E. L., and Knauth, L. P.: A calibration of the triple oxygen isotope fractionation in the $\mathrm{SiO}_{2}-\mathrm{H}_{2} \mathrm{O}$ system and applications to natural samples, Geochim. Cosmochim. Ac., 186, 105-119, https://doi.org/10.1016/j.gca.2016.04.047, 2016.

Sharp, Z. D., Wostbrock, J. A. G., and Pack, A.: Massdependent triple oxygen isotope variations in terrestrial materials, Geochem. Perspect. Lett., 7, 27-31, https://doi.org/10.7185/geochemlet.1815, 2018.

Sherwood, S. C., Ingram, W., Tsushima, Y., Satoh, M., Roberts, M., Vidale, P. L., and O'Gorman, P. A.: Relative humidity changes in a warmer climate, J. Geophys. Res.-Atmos., 115, D09104, https://doi.org/10.1029/2009JD012585, 2010.

Smith, S. E., Fendenheim, D. M., and Halbrook, K.: Epidermal conductance as a component of dehydration avoidance in Digitaria californica and Eragrostis lehmanniana, two perennial desert grasses, J. Arid Environ., 64, 238-250, https://doi.org/10.1016/j.jaridenv.2005.04.012, 2006.

Suavet, C., Alexandre, A., Franchi, I. A., Gattacceca, J., Sonzogni, C., Greenwood, R. C., Folco, L., and Rochette, P.: Identification of the parent bodies of micrometeorites with high-precision oxygen isotope ratios, Earth Planet. Sc. Lett., 293, 313-320, https://doi.org/10.1016/j.eps1.2010.02.046, 2010.

Surma, J., Assonov, S., Bolourchi, M. J., and Staubwasser, M.: Triple oxygen isotope signatures in evaporated water bodies from the Sistan Oasis, Iran, ResearchGate, 42, 8456-8462, https://doi.org/10.1002/2015GL066475, 2015. 
Surma, J., Assonov, S., Herwartz, D., Voigt, C., and Staubwasser, M.: The evolution of ${ }^{17} \mathrm{O}$-excess in surface water of the arid environment during recharge and evaporation, Sci. Rep.-UK, 8, 4972, https://doi.org/10.1038/s41598-018-23151-6, 2018.

Uemura, R., Barkan, E., Abe, O., and Luz, B.: Triple isotope composition of oxygen in atmospheric water vapor, Geophys. Res. Lett., 37, L04402, https://doi.org/10.1029/2009GL041960, 2010.

Vergutz, L., Manzoni, S., Porporato, A., Novais, R. F., and Jackson, R. B.: Global resorption efficiencies and concentrations of carbon and nutrients in leaves of terrestrial plants, Ecol. Monogr., 82, 205-220, https://doi.org/10.1890/11-0416.1, 2012.

Webb, E. A. and Longstaffe, F. J.: The oxygen isotopic compositions of silica phytoliths and plant water in grasses: Implications for the study of paleoclimate, Geochim. Cosmochim. Ac., 64, 767-780, 2000.

Webb, E. A. and Longstaffe, F. J.: Climatic influences on the oxygen isotopic composition of biogenic silica in prairie grass, Geochim. Cosmochim. Ac., 66, 1891-1904, 2002.
Webb, E. A. and Longstaffe, F. J.: The relationship between phytolith- and plant-water delta O-18 values in grasses, Geochim. Cosmochim. Ac., 67, 1437-1449, https://doi.org/10.1016/s0016-7037(02)01300-5, 2003.

Webb, E. A. and Longstaffe, F. J.: Identifying the $\delta^{18} \mathrm{O}$ signature of precipitation in grass cellulose and phytoliths: Refining the paleoclimate model, Geochim. Cosmochim. Ac., 70, 2417-2426, https://doi.org/10.1016/j.gca.2006.02.024, 2006.

Welp, L. R., Lee, X., Kim, K., Griffis, T. J., Billmark, K. A., and Baker, J. M.: $\delta^{18} \mathrm{O}$ of water vapour, evapotranspiration and the sites of leaf water evaporation in a soybean canopy, Plant Cell Environ., 31, 1214-1228, https://doi.org/10.1111/j.13653040.2008.01826.x, 2008.

Woodburn, T. L., Johnson, W. C., Mason, J. A., Bozarth, S. R., and Halfen, A. F.: Vegetation dynamics during the PleistoceneHolocene transition in the central Great Plains, USA, Holocene, 27, 155-163, https://doi.org/10.1177/0959683616652710, 2017. 